\title{
2021: O TEMPO, A HISTÓRIA E A PESQUISA
}

\author{
Dóris Bittencourt Almeida* \\ Terciane Ângela Luchese** \\ Tatiane de Freitas Ermel ${ }^{* * *}$ \\ Chris de Azevedo Ramil ${ }^{* * *}$
}

O raiar da segunda década do século XXI apresenta desafios contínuos e alguns novos para a ciência e a pesquisa histórico-educacional, mas também para o cotidiano da vida, enquanto cidadãos. Hartog (2017, p. 36) escreveu que "sim, a História ainda está aí: ela nos instrui, ela nos distrai, ela é nossa memória coletiva, nosso patrimônio, ela contribui também para nos responsabilizar, nós hoje, como cidadãos”. As palavras do autor, retiradas do livro em que problematiza a emergência do fenômeno memorial na contemporaneidade, reforçam a importância dos historiadores como aqueles responsáveis por trazerem "um pouco mais de inteligibilidade sobre o mundo e um aumento de lucidez aos seus concidadãos" (HARTOG, 2017, p. 36).

\footnotetext{
* Universidade Federal do Rio Grande do Sul (UFRGS), Porto Alegre/RS, Brasil.

${ }^{* *}$ Universidade de Caxias do Sul (UCS), Caxias do Sul/RS, Brasil.

${ }^{* * *}$ Universidad Complutense de Madrid (UCM), Madrid, Espanha.

${ }^{* * * *}$ Universidade Federal de Pelotas (UFPEL), Pelotas/RS, Brasil.
} 
Neste sentido, como editoras, leitores, autores e avaliadores da Revista História da Educação, somos instados a acreditar na História e prestar reverência a este periódico, considerando sua trajetória e importância na formação dos pesquisadores em História da Educação.

Como falar da Revista História da Educação, sem incluir a Associação Sul-Rio-Grandense de Pesquisadores em História da Educação -ASPHE? Afinal, a idealização do periódico foi uma das ações mais significativas de um grupo de pesquisadores que, no passado, começou a demarcar o campo da História da Educação no Rio Grande do Sul, estendendo-o a outras fronteiras. Assim, a ASPHE foi criada em 1995 e, logo em seguida, em 1997, aqueles pesquisadores lançaram a primeira publicação da Revista, com o objetivo de constituir-se num veículo de divulgação de estudos do campo historiográfico educacional, tendo como público-alvo professores, estudantes, pesquisadores e interessados em História da Educação.

Portanto, História da Educação foi a primeira revista brasileira especializada no gênero. O número inaugural foi lançado em 28 de abril de 1997, por ocasião do primeiro encontro da ASPHE, ocorrido em São Leopoldo/RS.

A revista está hospedada no portal do Scielo Brasil www.scielo.br/heduc - e no portal de revistas da Universidade Federal do Rio Grande do Sul, no endereço http://seer.ufrgs.br/asphe. Apresenta-se em formato online e com acesso aberto. O processo de submissão, avaliação, edição e publicação é feito por meio do Sistema Eletrônico de Editoração de Revistas Seer, tradução licenciada do Open Journal Systems - OJS.

Cabe destacar que, atualmente, a revista é custeada pela ASPHE, com recursos provenientes dos eventos anuais e das anuidades dos associados. Até 2018, a Revista recebia auxílio financeiro, concedido por meio de editais das agências financiadoras CNPq/CAPES, que foi de suma importância para a qualificação do periódico e seu processo de internacionalização. 
A revista História da Educação tem servido como veículo singular de divulgação de estudos no campo historiográfico educacional e, também, uma fonte importante de consulta dos pesquisadores da área. Em função desse trabalho, tem sido avaliada pelo Qualis da Capes, desde 2002, com conceito A e classificada como sendo de âmbito nacional. Na última avaliação, equivalente ao quadriênio 2013-2016, a RHE foi então qualificada como A1, o que é considerado um índice de excelência.

Ao avaliar a trajetória da Revista, observa-se que os artigos publicados têm fomentado significativamente discussões historiográficas, seja em relação a pressupostos epistemológicos, novas temáticas e objetos de pesquisa, seja em relação a documentos e categorias de análise.

Desde o início de sua publicação, o periódico tem se preocupado em trazer, em todos seus números, autores internacionais, de diversas procedências e instituições acadêmicas de prestígio na área de História da Educação. Pesquisadores da Alemanha, Argentina, Canadá, Chile, Colômbia, Espanha, Estados Unidos, França, Itália, México, Portugal, Uruguai, exemplificam alguns dos países presentes na revista. Na perspectiva de internacionalização, desde o n. 41/2013, os artigos de autores estrangeiros são publicados na língua de origem e em português. Tem-se procurado intensificar a publicação em textos em língua estrangeira, com vistas a atingir a diretriz de internacionalização proposta pelo Scielo e outros sites indexadores. Além da língua inglesa, a Revista publica artigos em espanhol, francês e italiano, com suas respectivas traduções (em português ou espanhol). Quanto aos autores nacionais, cada vez mais seus textos têm sido publicados tanto em português como em inglês. Mas isso necessita, ainda, ser universalizado para todos os artigos da revista.

Assim, ao observarmos os itinerários da Revista História da Educação, ao longo de todos esses anos, percebemos que o que se colhe hoje é tributário de muito trabalho e dedicação dos editores que nos antecederam. Elomar Tambara, Maria Helena Camara Bastos, Maria Stephanou, Claudemir de Quadros e outros colegas zelaram pela Revista para ela chegar até nós como um periódico de 
excelência. O que nos cabe? Prosseguir com o trabalho qualificado que nos foi legado por aqueles que nos precederam. Entretanto, sabemos das adversidades a serem enfrentadas, se não tivemos, mais uma vez, a colaboração de agências de fomento do país. Além disso, percebemos que as perspectivas não são boas no que se refere aos critérios de avaliação dos periódicos da área.

Neste momento, marcado pela desestabilização do lugar da História, observamos: uma perda ou diminuição substantiva de carga horária da disciplina de História da Educação na formação inicial e continuada de professores; que a pressão sobre educadores e intelectuais se acentua; armadilhas, revestidas no discurso da inovação e da qualidade educacional, mas que, de fato, privilegiam fazeres educativos meramente instrumentais, acríticos e desconectados com o pensar. Diante de todas essas constatações, reafirmamos que é preciso manter a convicção da importância da História. Importância essa, concretizada no valor de narrativas históricas que promovam a interrogação, o pensamento crítico, o aprofundamento analítico de saberes e conceitos, a visão contextualizada de acontecimentos, em que se suspeite de discursos que embaçam nossa posição e turvam a defesa de educação pública, democracia, direitos humanos, justiça social e preservação ambiental.

Hartog, no mesmo livro referenciado anteriormente, identifica o historiador como um "obstinado observador do presente, do seu presente" (2017, p. 84). Este é um presente desafiador, sem precedentes em nossas existências individuais, em que precisamos nos reinventar para resistir, em múltiplas dimensões. No entanto, como professores, pesquisadores e editoras, empenhados em defender nosso campo de docência e pesquisa, seguiremos em frente, com nosso trabalho, inspirados em "acreditar na História", mesmo diante de um tempo presente que nos traz tantas ameaças e inseguranças.

Editoras da Revista História da Educação 


\section{REFERÊNCIAS}

HARTOG, François. Crer em História. Belo Horizonte: Autêntica, 2017.

DÓRIS BITTENCOURT ALMEIDA

E-mail: almeida.doris@gmail.com

(i) http://orcid.org/0000-0002-4817-0717

TERCIANE ÂNGELA LUCHESE

E-mail: tercianeluchese@gmail.com

(1) http://orcid.org/0000-0002-6608-9728

TATIANE DE FREITAS ERMEL

E-mail: tatiane.ermel@gmail.com

(1) http://orcid.org/0000-0003-2002-5101

CHRIS DE AZEVEDO RAMIL

E-mail: chrisramil@gmail.com

(1) http://orcid.org/0000-0002-2338-0558

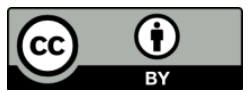

Revista História da Educação - RHE

Associação Sul-Rio-Grandense de Pesquisadores em História da Educação - Asphe

Artigo de acesso aberto distribuído nos termos de licença Creative Commons. 